\title{
Smart glass as the method of improving the energy efficiency of high-rise buildings
}

\author{
Olga Gamayunova ${ }^{1}$, Eliza Gumerova ${ }^{1, *}$ and Nadezda Miloradova ${ }^{2}$ \\ ${ }^{1}$ Peter the Great St. Petersburg Polytechnic University, 29 Politechnicheskaya St., St. Petersburg, \\ 195251, Russia \\ ${ }^{2}$ Moscow State University of Civil Engineering, Yaroslavskoye shosse, 26, Moscow, 129337, Russia
}

\begin{abstract}
The question that has to be answered in high-rise building is glazing and its service life conditions. Contemporary market offers several types of window units, for instance, wooden, aluminum, PVC and combined models. Wooden and PVC windows become the most widespread and competitive between each other. In recent times design engineers choose smart glass. In this article, the advantages and drawbacks of all types of windows are reviewed, and the recommendations are given according to choice of window type in order to improve energy efficiency of buildings.
\end{abstract}

\section{Introduction}

Today high-rise buildings are erected more often than it was even 10 years ago. It can be said that this fact becomes global. Claims on facade glazing for these houses differ markedly from requirements to windows of other. In view of some specific conditions unique window constructions will be required for upper zones of skyscrapers.

Furthermore, we should give consideration to energy consumption and conservation. Pride of place goes to windows since current state of its thermal protection is inferior to heat shield of wall envelopes [2].

In accordance with data of energy survey one of the reasons of energy loss is glazing in old wooden frames, which is installed mostly in budgetary organizations (kindergartens, schools, etc.). Obviously, these windows are subjected to be replaced. Energy and economic effectiveness depend on choice of type of window construction.

Heat losses through the window occur for several places: window units, air conduction losses and radiation.

It is clear that value of heat losses through the window unit directly depends on window construction, materials and manufacturing quality. In reality it is about $10 \%$ of whole heat losses [6-8].

In case of constant rate increase on electricity and heat, improvement of thermotechnical characteristics is consider to be one of the most effective ways to decide the problem of energy consumption.

\footnotetext{
*Corresponding author: eliza_gumerova@mail.ru
} 


\section{Main types of modern window structures}

The days, when windows were only wooden and have ordinary glazing, are gone. Innovative technologies and building materials improve significantly fabrication. Window products change their usual design and become variable, more functional and durable.

At the present time basic materials for window production in Russia are wood, aluminum and PVC. Due to various estimates, percent of plastic windows ranges from 60 to $80 \%$ of all translucent structures.

Each of these types of windows works both ways (table 1) and particular consumer [1]:

- PVC windows - the most economic glazing for industrial, public and residential buildings;

- aluminum windows come into operation gradually in residential houses, not only in industrial and public buildings;

- modern wooden windows refer to elite translucent structures and are settled mainly in premium-class flats and villas. Traditional windows are used in weekend cottages [9].

We consider in more details the main properties of PVC and wooden windows. In this article we will not deal with aluminum windows for its primary use in industrial buildings. Furthermore, since there is sufficiently frigid climate in Russia, the value of quantity of settled aluminum windows is small and cannot have an impact on energy effectiveness.

Table 1. Advantages and drawbacks of wooden, PVC and aluminum windows.

\begin{tabular}{|c|c|c|}
\hline Window & Advantages & Drawbacks \\
\hline Wooden & $\begin{array}{l}\text { - } \text { high strength of timber, low } \\
\text { density provide the high quality; } \\
\text { - high heat and sound } \\
\text { conductivity; } \\
\text { - high freezing resistance; } \\
\text { - environmental friendliness; } \\
\text { - appearance of natural } \\
\text { material; } \\
\text { - repair capability }\end{array}$ & $\begin{array}{l}\text { - } \text { presence of cracks and knots; } \\
\text { - } \text { putrescibility; } \\
\text { - } \text { hygroscopity; } \\
\text { - } \text { flammability; } \\
\text { - } \text { requirement for periodic } \\
\text { servicing (painting, etc.); } \\
\text { - necessity of ventilation; } \\
\text { - very high demands to } \\
\text { qualification of manufacturers } \\
\text { and windows fitters }\end{array}$ \\
\hline Aluminum & $\begin{array}{l}\text { - almost infinite life; } \\
\text { - high strength, low density; } \\
\text { - corrosion, deformation and } \\
\text { environmental hazard } \\
\text { resistance; } \\
\text { - lack of necessity to } \\
\text { servicing; } \\
\text { - ability to manufacture } \\
\text { windows of any forms and } \\
\text { dimensions }\end{array}$ & $\begin{array}{l}\text { - aluminum smelting is } \\
\text { energy-consuming and capital } \\
\text { intensive process; } \\
\text { - possibility of electrochemical } \\
\text { reactions; } \\
\text { - high heat conductivity; } \\
\text { - necessity of ventilation }\end{array}$ \\
\hline PVC & $\begin{array}{l}\text { - durability, weather } \\
\text { sustainability } \\
\text { - impermeability of all joints } \\
\text { - lack of necessity to } \\
\text { servicing; } \\
\text { - high heat and sound } \\
\text { conductivity }\end{array}$ & $\begin{array}{l}\text { - necessity of ventilation; } \\
\text { - very high demands to } \\
\text { qualification of manufacturers } \\
\text { and windows fitters }\end{array}$ \\
\hline
\end{tabular}




\section{Energy-conservating PVC windows}

Fast moving progress in production of energy-saving glazing can be one more argument for buildings with facade glazing. Energy-conserving coverings are made with using of nanotechnologies [10].

Energy efficient k- or i-glass are used in energy-saving windows. I-glass has better properties than k-glass. Differences between i- and k-glasses are as in the manufacturing technology as in the emissive coefficient. Application of window units with i-glass not only saves energy, but also increases the comfort of being in apartments.

Drawback of $\mathrm{i}$-glass is a low abrasion resistance that presents some particular difficulties during transportation. However, taking into account the fact that energy-conserving covering of i-glass is inside window unit, this disadvantage does not impact on operational characteristics of i-glass.

Advantages of energy-saving glass:

- one-chamber glass with $\mathrm{k}$ - or i-glass has more value than triple-pane window with traditional glass;

- one-chamber glass with energy-saving glass is lighter than triple-pane window, that provides extended operational period and decreases the load on window hardware;

- double-pane glass with low emissivity has more light transmission than two-chambered with customary glass;

- thanks to mass production the cost of one-chamber glass with i- or k-glass is nearly the same as of two-chambered with traditional glass [11].

\section{Smart-glass}

In recent years hi-tech solutions, for example "smart glass" with changeable transparence, are all the rage. Thanks to thin liquid-crystal film window transparency can be regulated by remote control panel. (Fig. 1)
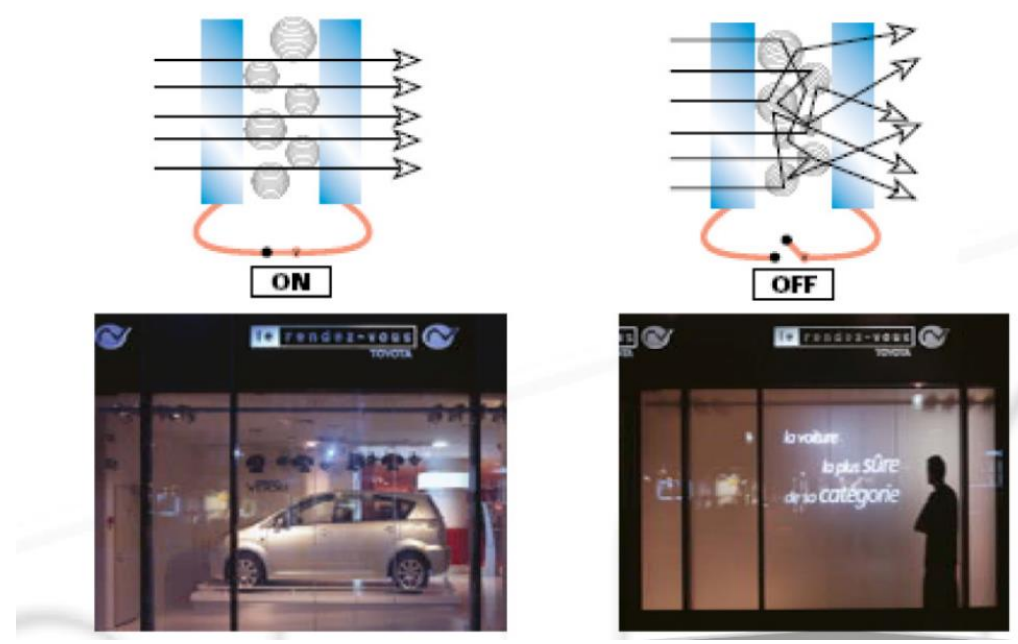

Fig. 1. Smart-glass [4]

Film with changeable matte appearance can be used in combination with various types of glass. The most appropriate variant of matte glass production is chosen due to some peculiarities: 
Table 2. Characteristics of ways of making glass with variable mat.

\begin{tabular}{|c|c|c|}
\hline $\begin{array}{c}\text { Variant of production of glass with changeable } \\
\text { matte surface }\end{array}$ & Appendix \\
\hline Triplex & & $\begin{array}{c}\text { Film between two glasses } \\
\text { for installation into frame } \\
\text { (dimension to } 3 \times 1.5 \mathrm{~m} \text { ) }\end{array}$ \\
\hline On glass & In window unit & $\begin{array}{c}\text { Film is applied on glass } \\
\text { (for big dimensions or all- } \\
\text { glass execution) }\end{array}$ \\
\hline & $\begin{array}{c}\text { Film is applied on glass } \\
\text { inside the window unit for } \\
\text { sound- or heat-insulated } \\
\text { structures (for installation } \\
\text { into frame) }\end{array}$ \\
\hline
\end{tabular}

Analysts note that smart-glass allows to decrease heat losses, cut down expenses on ventilation and lightning, and answers for alternative to louvre shades and curtains. Smartglass in clear state does not hold violet rays.

\section{Features of glazing in high-rise buildings}

It is not so long ago as the glazing of buildings was implemented by exceptionally standard windows and cases, but nowadays the following trends are visible distinctly in modern architecture [5]:

- increasing area of glazing (up to $80 \%$ of area of facade);

- enlargement of number of storeys in buildings;

- extensive use of window structures inside the buildings;

- increase of dimensions of applying elements of glazing;

- functional extension of glazing, which decreases consequences of negative factors of external environment [12-18].

It is necessary to execute glazing works taking into account architectural and planning concept of building or structure, environmental factors of building site, functional peculiarities and anticipating operating conditions.

There are several key features of glazing in high-rise buildings [3].

Glazing ought not to be a threat to human life and health as indoors, as outdoors during installation and maintenance works. Collapsed glazing and possible fall and wounds can be illustration of hazardous situations which are associated with glazing. Degree of risk is rising with increase of building height. Thus, it is needed to apply only the safety glass (harden, multi-layered, reinforced) or install protection obstacles.

Furthermore, the requirements to fire-resistance of glazing in multi-storey buildings are more strict because of more intensive air draft and long evacuation routes. As a result, air flow rises sharply in place of initial fire during the glass failure. In this case, combustion process intensifies abruptly and fire begins to dpread rapidly indoor. Fire-resistance of glazing is to have be sufficient in order to provide the safe escape time.

It is essential to define loads and actions, which will act on it taking into account that they can be easily changed due to height above ground.

It should be considered that wind load and solar radiation intensity enlarge, temperature and air pressure decrease with increase of height. 
As for the optical features, special attention is given to distortions in reflected light and color of applied glass. Daylight area enlarges and in this situation, the exterior of building is worsen markedly by the optical distortions and color inhomogeneity of glazing.

Glazing should maintain its operation abilities while meeting the operation and maintenance requirements during the full life of building. Glazing with the service life smaller, than it was expected, is ought to be replaceable or repairable. This question is relevant in high-rise buildings because maintenance operation, repair and replacement of outside glazing is complicated engineering problem.

Using of glass with self-cleaning coating can be recommended in order to increase operating life and reduce the time of maintenance operation.

\section{Conclusions}

To increase the energy efficiency, the priority should be given up to modernized structures of energy-saving windows, which can decrease energy consumption by $30 \%$ with high profitability of investments without wall insulation.

PVC window units gained popularity in Russia. Nevertheless, wooden windows are environmentally friendly, there is interchange of air in it, but they less resistant to moisture. That is why air will be fresher in rooms with wooden window units than in premises with PVC windows.

Applying of smart glass can solve the problem of safety and energy-saving glazing in high-rise buildings. It cuts down consumption by $40 \%$. According to forecasts, the volume of using the smart glass will be increased by 6 times, and operating income will be annually raised for $21.2 \%$ by 2022 year.

Finally, it is highly recommended to take account into increase of risks, that causes the necessity of more strict requirements to safety, complicacy of operation conditions of glazing due to increasing value of loads, growth of aesthetic requirements for whole daylight area.

\section{References}

1. Online resource. URL: http://www.techart.ru/files/publications/44-45.pdf

2. Online resource. URL: https://www.msesupplies.com/blogs/news/34196932-globalsmart-glass-market-to-grow-to-5-8-billion-usd-by-2020

3. Online resource. URL: http://www.oknamedia.ru/novosti/smart-steklo-novayarealnost-v-stekolnoy-industrii-45174

4. Online resource. URL: http://tybet.ru/content/articles/ index.php?SECTION_ID=371 \&ELEMENT_ID $=29320$

5. URL: glassinfo.ru/articles/

2006_01_osobenosti_proektirovania_osteklenia_visotn_zdani.pdf

6. Vatin N., Gamayunova O. Energy saving at home. Applied Mechanics and Materials, 672-674, 550-553 (2014)

7. Vatin N., Gamayunova O. Energy efficiency and energy audit: the experience of the russian federation and the republic of Belarus. Advanced Materials Research, 10651069, 2159 (2016)

8. Vatin N., Gamayunova O. Choosing the right type of windows to improve energy efficiency of buildings. Applied Mechanics and Materials, 633-634, 972-976 (2014) 
9. Vatin N., Gamayunova O. The role of the state and citizens in improving energy efficiency. Applied Mechanics and Materials, 725, 1493 (2015)

10. Vatin N., Gamayunova O., Nemova D. An energy audit of kindergartens to improve their energy efficiency. Advances in Civil Engineering and Building Materials IV Selected and Peer Reviewed Papers from the 2014 4th International Conference on Civil Engineering and Building Materials, CEBM 2014 4th, 305-308 (2015)

11. Gumerova E., Gamayunova O., Shilova L. The optimal decision of insulation in cladding structures for energy efficient buildings. MATEC Web of Conferences, 06020 (2017)

12. Vatin N.I., Nemova D.V., Tarasova D.S., Staritcyna A.A. Increase of energy efficiency for educational institution building. Advanced Materials Research, 953-954, 854-870 (2014)

13. Vatin N.I., Gorshkov A.S., et. Al.The energy-efficient heat insulation thickness for systems of hinged ventilated facades. Advanced Materials Research, 941-944, 905-920 (2014)

14. Kiryudcheva A.E., Shishkina V.V et. al. Energy efficiency of building envelopes for public buildings. Construction of Unique Buildings and Structures, 5 (44), 19-30 (2016)

15. V. Pukhkal, V. Murgul, IOP Conference Series: Earth and Environmental Science, 90, 012211 (2017) doi :10.1088/1755-1315/90/1/012211

16. N. Harmathy, V. Murgul, Procedia Engineering, 165, 1845 - 1852 (2016) DOi10.1016/j.proeng.2016.11.932

17. A Gorshkov, V. Murgul, Advances in Intelligent Systems and Computing, 692, 577 591 (2018) DOi - 10.1007/978-3-319-70987-1_61

18. N. Harmathy, J. Kontra, V. Murgul, Z. Magyar, Advances in Intelligent Systems and Computing, 692, 563 - 576 (2018) DOi- 10.1007/978-3-319-70987-1_60 